\title{
Consumption of Cinara spp. (Hemiptera, Aphididae) by Cycloneda sanguinea (Linnaeus, 1763) and Hippodamia convergens Guérin-Méneville, 1842 (Coleoptera, Coccinellidae) ${ }^{1}$
}

\author{
Josiane Teresinha Cardoso² \\ Sonia Maria Noemberg Lázzari²
}

\begin{abstract}
Adults and larvae of coccinellids were observed feeding on populations of the giant conifer aphids Cinara spp. on Pinus spp., in Southern Brazil. The objective of this research is to evaluate the consumption capacity of Cycloneda sanguinea (Linnaeus, 1763) and Hippodamia convergens Guérin-Méneville, 1842 (Coleoptera, Coccinellidae) on these aphid species, in order to obtain information for biological control programs. Ten larvae of each predator species were fed with aphids of small size (nymphs of $1^{\text {st }}$ and $2^{\text {nd }}$ instars), and 10 with aphids of medium size (nymphs of $3^{\text {rd }}$ and $4^{\text {th }}$ instars), maintained under $15^{\circ} \mathrm{C}, 20^{\circ} \mathrm{C}$ and $25^{\circ} \mathrm{C}, 12 \mathrm{~h}$ photophase and $70 \pm 10 \%$ relative humidity. The aphids were counted every 24 hours, replacing those that were consumed. The total consumption of Cinara by the larvae of C. sanguinea was not statistically different at the three temperatures: $325.5 ; 322.2$ and 324.8 of small aphids and $121.3 ; 140.4$ and 109.9 of medium ones, respectively at $15^{\circ} \mathrm{C}, 20^{\circ} \mathrm{C}$ and $25^{\circ} \mathrm{C}$. The consumption by $H$. convergens was higher than by $C$. sanguinea and increased noticeably with temperature: 444 aphids at $15^{\circ} \mathrm{C} ; 491.3$ at $20^{\circ} \mathrm{C}$ and 513.3 at $25^{\circ} \mathrm{C}$, considering the small aphids, and 187.1; 205.1 and 216.6 of medium aphids at the three temperatures. The small aphids weigh about half as much as medium ones and were preferred by all larval instars probably because they are easier to manipulate than the large ones. Both predators, especially the $4^{\text {th }}$ instar larvae, showed high consumption capacity on the Cinara nymphs at all temperatures and can be regarded as promising biological control agents.
\end{abstract}

KEYwORDs. Biological control; giant conifer aphids; Pinaceae; prey-predator relationship.

\section{INTRODUCTION}

The species Pinus taeda (L.) and Pinus elliottii (Engelmann) (Pinaceae) have great economic importance in Brazil, especially for the lumber, paper and wood products industry. There are 2.0 million ha of Pinus reforestation in the country, particularly in the Southern and Southeastern regions.

Two species of Cinara Curtis, 1835 (Hemiptera, Aphididae) were introduced into Brazil in the 1990's and caused severe outbreaks: Cinara pinivora (Wilson, 1919) and Cinara atlantica (Wilson, 1919) (E. Iede, S. Lázzari and R. C. Carvalho, personal communication) on Pinus spp.. The compact colonies are composed by apterous and alate adults and nymphs of all instars feeding on the trunk and branches. The main symptoms of an infestation are premature needle shedding, destruction of the apical bud, oversprouting, and height reduction, which are accentuated in young trees (PENTEAdo et al. 2000). The population peak occurs during the winter, but $C$. atlantica is rapidly adapting to warmer regions and can be found throughout the year, while $C$. pinivora is more restricted to cooler regions, with average winter temperature of $15^{\circ} \mathrm{C}$ (personal observations).

Since they are exotic and newly introduced pests, there is only a reduced number of predator species to suppress the populations in the field (chrysopids and coccinellids), but no parasitoids have been registered so far. Potential natural enemies have to bee sought because chemical control measures are neither economically nor ecologically viable.

The coccinellids Cycloneda sanguinea (Linnaeus, 1763) and Hippodamia convergens Guérin-Méneville, 1842 (Coleoptera: Coccinellidae) were observed preying on the colonies on Pinus spp. in the State of Paraná. It is known that

1. Contribuição $n^{\circ} 1379$ do Departamento de Zoologia, Universidade Federal do Paraná.

2. Departamento de Zoologia, Universidade Federal do Paraná. Caixa Postal 19020, 81531-980 Curitiba-PR, Brasil. Bolsistas do CNPq.

E-mail: lazzari@ufpr.br 
coccinellids are very efficient control agents of several aphid species (SANTOS \& Pinto 1981; Trouve et al. 1997 and MiRANDA et al. 1998). The factors that influence the feeding process and efficiency of these predators as biological control agents are: voracity (maximum number of prey consumable by the predator), functional response (relationship between number of captured preys and number of preys present), numerical response (increase in predator number with the increase in prey density) and the prey preference, as well as prey capture efficiency of the predator. All of these factors are intimately linked to temperature (FRAZER 1988). It means that development, feeding and temperature are inseparable factors when considering candidate species for biological control programs, and they should be evaluated together.

Therefore, the objective of this research is to determine the consumption capacity of $C$. sanguinea and $H$. convergens feeding on Cinara nymphs under different temperatures.

\section{MATERIAL AND METHODS}

The populations of Cinara spp. and the predator eggs were collected directly from Pinus spp., in Curitiba and Rio Negro cities, State of Paraná, and kept at $25^{\circ} \mathrm{C}$, on pine seedlings, in laboratory cages. In order to evaluate the efficiency of prey manipulation by the different instars of the predator larvae, the aphids were separated in two categories: small size aphids, corresponding to $1^{\text {st }}$ and $2^{\text {nd }}$ instar nymphs and medium aphids, $3^{\text {rd }}$ and $4^{\text {th }}$ instar nymphs. On average, the small ones weighed $0.00043 \mathrm{~g} / \mathrm{aphid}$, while the medium ones weighed $0.00087 \mathrm{~g} /$ aphid, about twice as much. Adult aphids were not used for the tests due to the difficulty of controlling the continuous deposition of nymphs.

For each treatment, 20 newly emerged, non-sexed larvae of each predator species were placed individually in $120 \mathrm{~mL}$ transparent plastic receptacles, with filter paper on the bottom and covered with transparent plastic film. A known number of Cinara nymphs were released daily in each vial: ten $1^{\text {st }}$ instar larvae were fed small aphids and the other ten medium aphids. The receptacles were placed in chambers at $15^{\circ} \mathrm{C}, 20^{\circ} \mathrm{C}$ and $25^{\circ} \mathrm{C}$, with photophase of $12 \mathrm{~h}$ and $70 \pm 10 \%$ of relative humidity. The aphids were counted and replaced every $24 \mathrm{~h}$, evaluating separately the consumption of each larval instar until pupation. Those larvae that did not complete development were not considered in the analyses.

For $C$. sanguinea, the consumption by the adults was also evaluated. At $15^{\circ} \mathrm{C}$ and $25^{\circ} \mathrm{C}$ the observation was conducted for 30 days; at $20^{\circ} \mathrm{C}$, the consumption was evaluated during the whole period of the adult life, using the same methodology adopted for the larvae. A simple statistical analysis was applied to measure the consumption by each larval instar and a regression analysis to evaluate the influence of temperature on consumption.

\section{RESULTS AND DISCUSSION}

Prey consumption by larvae and adults of Cycloneda sanguinea. Prey consumption by larvae of $C$. sanguinea increased significantly from the first to the fourth instar under the three temperatures (Tab. I). The mean aphid consumption during the complete larval period was not statistically different among temperatures, considering both aphid sizes; although there are some differences among some instars. It can be observed that the consumption of small aphids was about three times that of the medium ones, while their weight was only half; it is probably due to the easiness to manipulate smaller prey, especially by the first instar larvae.

The regression analysis, as observed on Fig. 1 and by the $\mathrm{R}^{2}$, confirms that the temperature did not influence the consumption by any of the instars: $R^{2}=0.2863\left(y=0.1647 x^{2}-\right.$ $6.935 \mathrm{x}+86.714)$ for the $1^{\text {st }}$ instar; $\mathrm{R}^{2}=0.2921\left(\mathrm{y}=0.0639 \mathrm{x}^{2}-\right.$ $0.665 \mathrm{x}=24.857)$ for the $2^{\text {nd }} ; \mathrm{R}^{2}=0.0471\left(-0.1263 \mathrm{x}^{2}+4.38 \mathrm{x}+\right.$ $25.714)$ for the $3^{\text {rd }}$; and $R^{2}=0.0273\left(y=-0.1361 x^{2}+4.2375 x+\right.$ $180.68)$ for the $4^{\text {th }}$ larval instar, considering the predation of small aphids. For the consumption of medium aphids, the

Table I. Mean consumption (standard deviation and confidence interval at $95 \%$, in parenthesis) of nymphs of Cinara spp. by larvae of Cycloneda sanguinea, under three temperatures, $12 \mathrm{~h}$ of photophase and $70 \pm 10 \%$ relative humidity.

\begin{tabular}{lcccccc}
\hline & \multicolumn{3}{c}{ SMALL APHIDS $(\mathrm{n}=10)$} & \multicolumn{3}{c}{ MEDIUM APHIDS (n=10) } \\
\hline \multirow{3}{*}{$1^{\text {st }}$ instar } & $15^{\circ} \mathrm{C}$ & $20^{\circ} \mathrm{C}$ & $25^{\circ} \mathrm{C}$ & $15^{\circ} \mathrm{C}$ & $20^{\circ} \mathrm{C}$ & $25^{\circ} \mathrm{C}$ \\
& $19.7(3.1)$ & $13.9(2.9)$ & $16.2(6.2)$ & $6.0(2.9)$ & $5(1.4)$ & $7.1(1.2)$ \\
& $(17.7-22.3)$ & $(11.2-16.5)$ & $(10.5-22.1)$ & $(3.2-8.7)$ & $(3.9-6.1)$ & $(6.2-7.9)$ \\
$2^{\text {nd }}$ instar & $29.2(5.9)$ & $37.1(5.1)$ & $48.1(21.4)$ & $10.4(2.5)$ & $14.2(4.0)$ & $11.5(2.7)$ \\
& $(24.2-34.2)$ & $(30.8-43.3)$ & $(40.6-55.6$ & $(8.4-12.2)$ & $(12.4-15.9)$ & $(9.7-13.2)$ \\
$3^{\text {rd }}$ instar & $63.0(9.5)$ & $62.8(10.9)$ & $56.2(21.2)$ & $23.4(4.1)$ & $29.6(4.1)$ & $26.1(8.1)$ \\
& $(54.9-71.0)$ & $(54.9-70.6)$ & $(36.6-75.9)$ & $(19.5-27.2)$ & $(26.6-32.5)$ & $(20.3-31.8)$ \\
$4^{\text {th }}$ instar & $213.6(29.3)$ & $211(26.5)$ & $201.5(38.5)$ & $81.5(12.3)$ & $91.6(6.7)$ & $65.2(10.4)$ \\
& $(189.1-238.1)$ & $(192.0-229.9)$ & $(165.9-237.2)$ & $(75.2-87.9)$ & $(86.2-96.9)$ & $(59.8-70.5)$ \\
\hline Total & $325.5(40.2)$ & $322.2(26)$ & $324.8(19.9)$ & $121.3(15.4)$ & $140.4(7.7)$ & $109.9(14.1)$ \\
& $(291.6-359.2)$ & $(306.1-343.4)$ & $(303.8-340.7)$ & $(107.1-135.6)$ & $(134.8-145.9)$ & $(99.8-119.9)$ \\
\hline
\end{tabular}



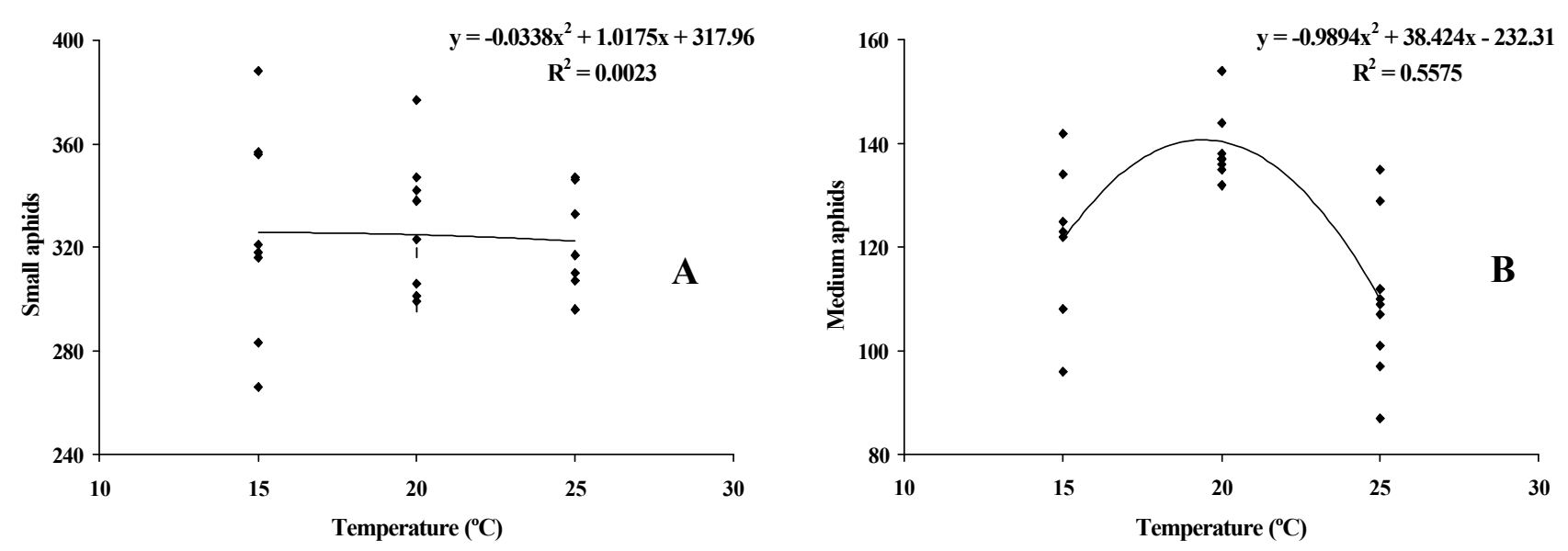

Fig. 1. Regression model adjusted to the total consumption by larvae of Cycloneda sanguinea fed with (A) $1^{\text {st }}$ and $2^{\text {nd }}$ and (B) $3^{\text {rd }}$ and $4^{\text {th }}$ instar nymphs of Cinara spp. under three temperatures, $12 \mathrm{~h}$ of photophase and $70 \pm 10 \%$ relative humidity.

following equations were obtained for the $1^{\text {st }}, 2^{\text {nd }}, 3^{\text {rd }}$ and $4^{\text {th }}$ instar larvae, respectively: $\mathrm{R}^{2}=0.2063\left(\mathrm{y}=0.062 \mathrm{x}^{2}-2.37 \mathrm{x}+\right.$ $27.6) ; R^{2}=0.2111\left(y=-0.1294 x^{2}+5.2843 x+39.714\right) ; R^{2}=0.1633$ $\left(\mathrm{y}=-0.1934 \mathrm{x}^{2}+8.0043 \mathrm{x}+53.114\right) ;$ and $\mathrm{R}^{2}=0.6005(\mathrm{y}=$ $\left.0.7286 x^{2}+27.506 x+167.09\right)$.

GuRney \& Hussey (1970), studying the effect of the temperature on the consumption of Myzus persicae (Sulzer, 1776) by $C$. sanguinea, observed an increase in prey consumption as a function of temperature, contrary to the findings of the present research. However, those same authors affirm that comparisons are only valid for identical methodological conditions, besides, there is a great variability among individuals of the same species and much more between species (Tab. I). ARnt \& Fagundes (1982) evaluated the consumption of nymphs of the aphids Rhopalosiphum maidis (Fitch, 1856) and Sitobion avenae (Fabricius, 1775) during the development of $C$. sanguinea, under temperatures between $22^{\circ} \mathrm{C}$ and $28^{\circ} \mathrm{C}$, and they found a mean consumption of 157 aphids for the total period, and it was especially high during the last two larval instars, similar to what was observed here, although, they do not separate the aphids by size.

The adults of $C$. sanguinea presented an average consumption of 6.6 aphids/day at $15^{\circ} \mathrm{C} ; 17.5$ aphids/day at $20^{\circ} \mathrm{C}$; and 32.2 aphids/day at $25^{\circ} \mathrm{C}$, during the first 30 days of adult life, indicating a tendency for increased daily consumption related to the elevation of temperature. At $20^{\circ} \mathrm{C}$ the adult longevity was 167 days and the consumption averaged 1997 aphids during this period.

Prey consumption by larvae of Hippodamia convergens. The consumption of nymphs of Cinara by the larvae of this coccinellid species increased significantly from one instar to the next; particularly in the last larval instar when the larvae consumed more than $50 \%$ of the total, under the three temperatures (Tab. II).

Considering the influence of temperature on total

Table II. Mean consumption (standard deviation and confidence interval at 95\%, in parenthesis) of nymphs of Cinara spp. by larvae of Hippodamia convergens, under three temperatures, $12 \mathrm{~h}$ of photophase and $70 \pm 10 \%$ relative humidity.

\begin{tabular}{|c|c|c|c|c|c|c|}
\hline & \multicolumn{3}{|c|}{ SMALL APHIDS $(\mathrm{n}=10)$} & \multicolumn{3}{|c|}{ MEDIUM APHIDS $(\mathrm{n}=10)$} \\
\hline & $15^{\circ} \mathrm{C}$ & $20^{\circ} \mathrm{C}$ & $25^{\circ} \mathrm{C}$ & $15^{\circ} \mathrm{C}$ & $20^{\circ} \mathrm{C}$ & $25^{\circ} \mathrm{C}$ \\
\hline \multirow[t]{2}{*}{$1^{\text {st }}$ instar } & $25.5(8.2)$ & $13.7(2.2)$ & $29.6(5.3)$ & $9.1(3.4)$ & $6.3(1.5)$ & $7(1.4)$ \\
\hline & $(17.9-33.1)$ & $(10.4-16.7)$ & $(26.4-32.7)$ & $(5.9-12.3)$ & $(5.1-7.4)$ & $(5.7-8.2)$ \\
\hline \multirow[t]{2}{*}{$2^{\text {nd }}$ instar } & $68.1(19.6)$ & $39.8(6.5)$ & $43.7(6.4)$ & $23.6(5,3)$ & $19.6(5.1)$ & $16.2(2.2)$ \\
\hline & $(49.9-86.3)$ & $(34.3-45.3)$ & $(37.5-49.8)$ & $(18.6-28.4)$ & $(15.6-23.4)$ & $(14.6-17.7)$ \\
\hline \multirow[t]{2}{*}{$3^{\text {rd }}$ instar } & $104.7(33.3)$ & $79.5(9.4)$ & $70.8(9.5)$ & $45.6(10.1)$ & $31.3(5.7)$ & $30.5(3.8)$ \\
\hline & $(90-111.7)$ & $(71.5-87.4)$ & $(58.6-77.5)$ & $(41.3-49.8)$ & $(27.5-35.1)$ & $(26.9-34)$ \\
\hline \multirow[t]{2}{*}{$4^{\text {th }}$ instar } & $245.7(70.8)$ & $358.2(46.8)$ & $369.2(43.7)$ & $108.8(48.7)$ & $147.9(16.0)$ & $162.9(10.7)$ \\
\hline & $(210.9-280.2)$ & $(325.8-390.6)$ & $(340.2-398.1)$ & $(97.9-129.7)$ & $(135.5-160.2)$ & $(155.2-170.5)$ \\
\hline \multirow[t]{2}{*}{ Total } & $444(54.2)$ & $491.2(53.2)$ & $513.3(49.0)$ & $187.1(47.3)$ & $205.1(18.8)$ & $216.6(11.3)$ \\
\hline & $(393.8-494.1)$ & $(446.8-535.9)$ & $(478.2-548.3)$ & $(143.3-230.8)$ & $(190.6-219.5)$ & (208.4-224.7) \\
\hline
\end{tabular}



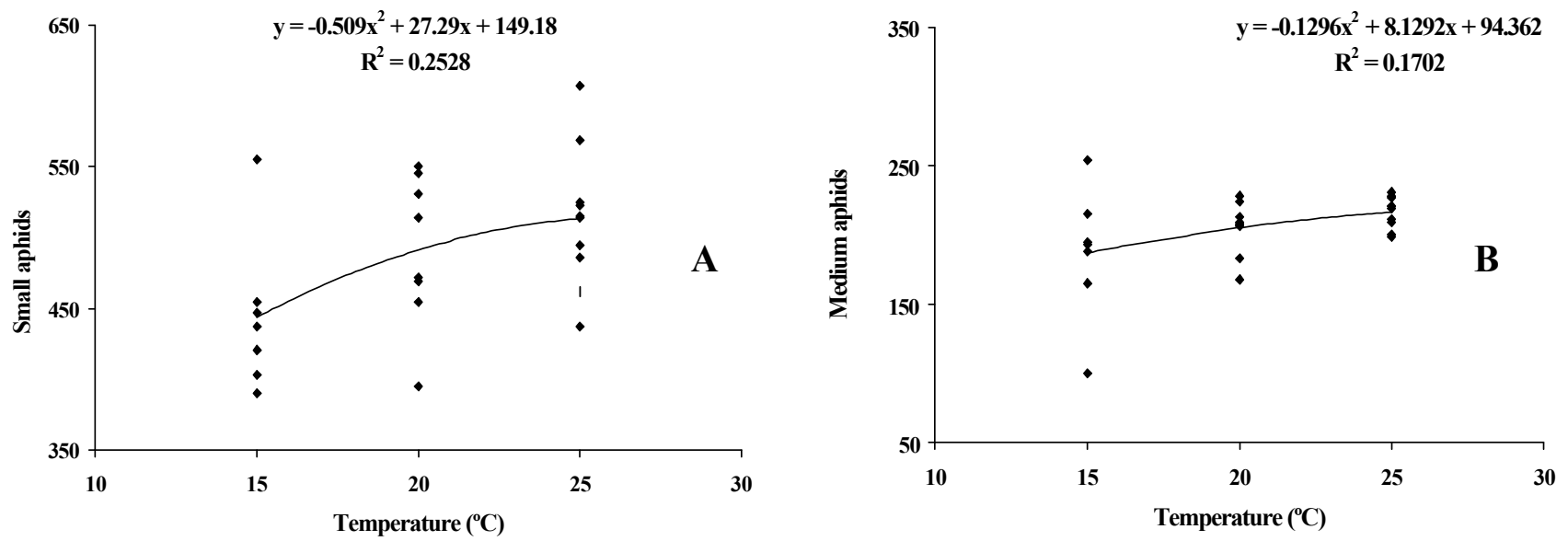

Fig. 2. Regression model adjusted to the total consumption by larvae of Hippodamia convergens fed with (A) $1^{\text {st }}$ and $2^{\text {nd }}$ and (B) $3^{\text {rd }}$ and $4^{\text {th }}$ instar nymphs of Cinara spp. under three temperatures, $12 \mathrm{~h}$ of photophase and $70 \pm 10 \%$ relative humidity.

consumption, it was observed that it was directly proportional to the increase of temperature, but the differences were not significant for either aphid size (Tab. II). GuRNEY \& HusSEY (1970) observed the same tendency increased consumption with increased temperature for $C$. sanguinea fed with $M$. persicae. On the other hand, Gyenge et al. (1998) found a tendency for increased consumption with decreased temperature for Eriopis connexa (Germar, 1824), fed with Acyrtosiphon pisum (Harris, 1776) and Schizaphis graminum (Rondani, 1852) at five different densities.

Similar to what happened to $C$. sanguinea, the regression analysis did not support the influence of temperature on consumption (Fig. 2). With the small aphids, the $\mathrm{R}^{2}$ obtained were: $\mathrm{R}^{2}=0.626\left(\mathrm{y}=0.5584 \mathrm{x}^{2}-21.934+228.94\right)$ for the $1^{\text {st }}$ instar; $\mathrm{R}^{2}=0.5329\left(\mathrm{y}=0.54695 \mathrm{x}^{2}-24.319+228.94\right)$ for the $2^{\text {nd }} ; \mathrm{R}^{2}=$ $0.3695\left(\mathrm{y}=0.2103 \mathrm{x}^{2}-11.803+234.44\right)$ for the $3^{\text {rd }}$; and $\mathrm{R}^{2}=0.5331$ $\left(y=-2.0346 x^{2}+93.746-702.84\right)$ for the last instar. The equations obtained for the consumption of medium aphids by the four larval instars were: $\mathrm{R}^{2}=0.3287\left(\mathrm{y}=0.0822 \mathrm{x}^{2}-3.5889+45.333\right)$; $\mathrm{R}^{2}=0.3463\left(\mathrm{y}=0.0132 \mathrm{x}^{2}+1.2654+39.58\right) ; \mathrm{R}^{2}=0.4133(\mathrm{y}=$ $\left.0.1214 \mathrm{x}^{2}-6.3643+113.71\right)$; and $\mathrm{R}^{2}=0.4152\left(\mathrm{y}=-0.4804 \mathrm{x}^{2}+\right.$ $24.621+152.36$ ).

Comparison of the larval consumption between the two predator species. When comparing the mean consumption of small and medium aphids by the larvae of the two predators, it is observed that the consumption was rather high for both species. The total consumption by $H$. convergens showed the tendency to increase with temperature, while $C$. sanguinea did not show much variation in response to temperature.

To determine the efficiency of predation of each species one should consider, in addition to consumption, the development and the mortality at different temperatures, but it can be said that $H$. convergens was more efficient at $25^{\circ} \mathrm{C}$, while $C$. sanguinea presented similar consumption capacity at the three temperatures. Considering that the species of Cinara have their population peak during the winter, the consumption capacity at $15^{\circ} \mathrm{C}$ should be used as reference. But, since there was no statistical difference between the consumption of the two species at this temperature, nor among temperatures, both species can be considered as potential biological control agents of Cinara on pine trees.

\section{REFERENCES}

ARnt, T. A. \& A. C. FAgundes. 1982. Observações sobre a biologia e ação predatora da larva de Cycloneda sanguinea (L.) (Coleoptera: Coccinellidae) sobre pulgões. Trigo e Soja 62: 33-35.

Frazer, B. D. 1988. Predators, p. 217-230. In: A. K Minks. \& P. Harrewijn. (Eds). Aphids, their biology, natural enemies and control. Amsterdam, Elsevier, Vol. 2B, 364p.

Gurney, B. \& N. W. Hussey. 1970. Evaluation of some coccinellid species for the biological control of aphids in protected cropping. Annals of Applied Biology 65: 451-458.

Gyenge, J. E.; J. D. Edelstein \& C. E. Salto. 1998. Efectos de la temperatura y la dieta en la biología de Eriopis connexa (Germar) (Coleoptera: Coccinellidae). Anais da Sociedade Entomológica do Brasil 27: 345-356.

Miranda, M. M. M.; M. Picanço; A. L. Matioli \& A. Pallini-Filho. 1998. Distribuição na planta e controle biológico de pulgões (Homoptera: Aphididae) em tomateiros. Revista Brasileira de Entomologia 42: 13-16.

Penteado, S. R. C.; R. F. Trentini; E. T. Iede \& W. Reis-Filho. 2000. Pulgão do Pinus: nova praga florestal. Série Técnica IPEF 13: 97-102.

SAntos, G. P. \& A. C. Q. Pinto. 1981. Biologia de Cycloneda sanguinea e sua associação com pulgão em mudas de mangueira. Pesquisa Agropecuária Brasileira 16: 473-476.

Trouve, C.; S. Ledee; A. Ferran \& J. Brun. 1997. Biological control of the damson-hop aphid, Phorodon humuli (Hom.: Aphididae), using the lady beetle Harmonia axyridis (Col.: Coccinellidae). Entomophaga 42: $57-62$. 